\title{
Outer Membrane Proteins of Fusobacterium nucleatum Fev1
}

\author{
By VIDAR BAKKEN* AND HARALD B. JENSEN \\ Department of Biochemistry, University of Bergen, Arstadveien 19, 5000 Bergen, Norway
}

(Received 13 May 1985; revised 27 November 1985)

\begin{abstract}
Outer membrane enriched material from six strains of Fusobacterium nucleatum was analysed by SDS-PAGE. The protein profiles of all the strains were dominated by proteins with molecular masses of about $40 \mathrm{kDa}$, and a very high degree of homology in relation to apparent molecular masses was observed. In all strains except Fevl, one of the most dominant proteins exhibited heat modifiable properties, having an apparent molecular mass of about $38 \mathrm{kDa}$ and $42 \mathrm{kDa}$ when heated in SDS at 50 and $100^{\circ} \mathrm{C}$, respectively. None of the proteins of the outer membrane of $F$. nucleatum Fevl demonstrated such heat modifiable properties. The $40 \mathrm{kDa}$ protein, and several other proteins, appear to be both exposed on the cell surface and peptidoglycan associated.
\end{abstract}

\section{INTRODUCTION}

The genus Fusobacterium consists of obligately anaerobic Gram-negative rods having as their habitat the mucous membranes of man and animals; diseases caused by these bacteria show characteristic inflammation followed by ulceration and necrosis. $F$. nucleatum is a member of the oral microflora. It is regularly found in human dental plaque associated with periodontal disease (Socransky, 1970; Van Palenstein-Helderman, 1975), and it is always present in diseases like necrotizing ulcerative gingivitis (ANUG) and cancrum oris (Hofstad, 1981).

It is assumed that components of the outer membrane, among them proteins, are involved in the pathogenesis of infection by Gram-negative bacteria (Buchanan \& Pearce, 1979; Hofstra et al., 1980). Besides the polysaccharide portion of LPS, a number of outer membrane proteins can be exposed on the surface of the cell, and these may serve as diffusion pores, specific substrate binding site proteins and mitogens (DiRienzo et al., 1978; Lugtenberg \& Van Alphen, 1983). They may also serve as antigens and have been considered as vaccine candidates (Blaser et al., 1984; Buchanan \& Pearce, 1979; Gilleland et al., 1984). The outer membrane proteins of fusobacteria have hitherto received little attention. Evidence has been presented indicating that outer membrane proteins are involved in corncob formation between $F$. nucleatum and Streptococcus sanguis (Lancy et al., 1983). The capability of $F$. nucleatum to bind to erythrocytes of many species (Falkler \& Hawley, 1977) is seemingly mediated by a fusobacterial haemagglutinin and evidence has been presented that this is a cell surface exposed protein or is dependent on such a protein for function (Dehazya \& Coles, 1980, 1982). These molecular interactions presumably do not involve filamentous surface structures, since examination of cells and cell fragments by various techniques failed to demonstrate the presence of pili or flagella (Dahlén et al., 1978). A group reactive protein antigen, designated $\mathrm{P} 2$, was isolated by Kristoffersen $(1969 a, b)$. DiRienzo \& Rosan (1984) presented data on a heat-modifiable protein isolated from the envelope of $F$. nucleatum strain 364 .

As a first approach towards an understanding of the role of the outer membrane proteins of $F$. nucleatum in pathogenicity, we decided to investigate the composition and localization of proteins in the cell wall. Various techniques for preparation of outer membrane enriched material were compared with respect to their suitability, and the protein composition was analysed by SDS-PAGE. 


\section{METHODS}

Bacteria. F. nucleatum strains FI, F3, F6 and F14 were gifts from T. Hofstad, Bergen; ATCC 10953 was from the American Type Culture Collection, Rockville, Md., USA, and Fevl was provided by S. E. Mergenhagen, Bethesda, Md. Bacteria were grown anaerobically in the medium described by Vasstrand et al. (1979), using ascorbic acid as the reducing agent, and were harvested in the mid to late exponential phase of growth.

Selective solubilization of inner membranes. The harvested cells were washed in cold $0.03 \mathrm{M}-\mathrm{Tris} / \mathrm{HCl}, \mathrm{pH} 8 \cdot 1$, resuspended in the same buffer and broken by one passage through a French pressure cell at about $3000 \mathrm{lbf}^{-2} \mathrm{in}^{-2}$ (20.7 MPa). After centrifugation at $2000 \mathrm{~g}$ for $5 \mathrm{~min}$ to remove unbroken cells (a very small pellet), the cell envelopes were sedimented by centrifugation at $10000 \mathrm{~g}$ for $15 \mathrm{~min}$ at $4{ }^{\circ} \mathrm{C}$. The envelope fraction was washed

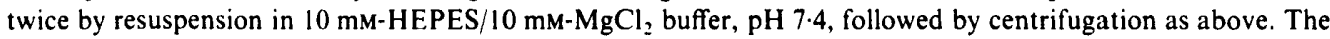
non-ionic detergent Triton X-100 was added to $2 \%(\mathrm{v} / \mathrm{v})$ concentration and the mixture incubated at room temperature for $20 \mathrm{~min}$. After centrifugation at $10000 \mathrm{~g}$ for $15 \mathrm{~min}$ at $4{ }^{\circ} \mathrm{C}$, the pellet was washed twice in $10 \mathrm{~mm}$ HEPES/ $/ 10 \mathrm{~mm}-\mathrm{MgCl}_{2}$. The protein content of the Triton X-100 insoluble material was estimated to be $30 \%$ of the dry weight (Table 1).

Sucrose density gradient centrifugation. The procedure used was in essence that described by Ito et al. (1977). Concentrations of sucrose between 50 and $60 \%(w / v)$ were used to separate the inner and the outer membranes according to their buoyant densities.

Radioiodination of bacteria. Labelling with ${ }^{125}$ I was done according to the method of Marchalonis (1969). To $200 \mu \mathrm{l}$ cell suspension $\left(5 \times 10^{8}\right.$ cells $\left.\mathrm{ml}^{-1}\right)$ in $0.02 \mathrm{M}$-phosphate buffer, $0.9 \%(\mathrm{w} / \mathrm{v}) \mathrm{NaCl}$, pH $7 \cdot 1$, was added $500 \mu \mathrm{Ci}(18.5 \mathrm{MBq}) \mathrm{Na}^{125} \mathrm{I}, 5 \mu \mathrm{g}$ lactoperoxidase and $8 \times 10^{-5} \mathrm{M}-\mathrm{H}_{2} \mathrm{O}_{2}$. The reaction was stopped after $10 \mathrm{~min}$ with $10 \mu \mathrm{l} 1 \mathrm{M}$-2-mercaptoethanol (2-ME), followed by $800 \mu \mathrm{l}$ cell suspension. The cells were sedimented $(10000 \mathrm{~g}$ for $10 \mathrm{~min}$ ) and Triton X-100 insoluble cell envelope material was prepared as described above. After analysis by SDS-PAGE, the gels were laid onto Kodak X-Omat films for autoradiography.

SDS-PAGE. Membrane proteins were separated by SDS-PAGE according to the method of Laemmli (1970). The concentration of polyacrylamide in the separating gel was $15 \%(\mathrm{w} / \mathrm{v})$ unless otherwise stated. The proteins were stacked in $4 \%$ polyacrylamide gel. Samples were heated in the sample buffer at $100^{\circ} \mathrm{C}$ for $5 \mathrm{~min}$, or at different temperatures in experiments to determine the degree of heat modifiability and peptidoglycan association. Samples containing $10-30 \mu \mathrm{g}$ or $0 \cdot 1-1 \mu \mathrm{g}$ protein were applied to gels when they were stained with Coomassie brilliant blue R250 or silver, respectively. Silver staining was done according to Marshall \& Latner (1981), with the modifications that all steps were done at $50{ }^{\circ} \mathrm{C}$, employing ammonia in the diamine step, and $2 \%$ (v/v) glutaraldehyde. Bio-Rad low molecular weight protein standards were used as size markers.

Peptidoglycan association. Membrane fractions were suspended in a buffer containing $10 \mathrm{~mm}-\mathrm{Tr}$ is $/ \mathrm{HCl}, \mathrm{pH} 7 \cdot 4$, $10 \%(\mathrm{v} / \mathrm{v})$ glycerol, $2 \%(\mathrm{w} / \mathrm{v}) \mathrm{SDS}$ and $0.7 \%(\mathrm{v} / \mathrm{v}) 2-\mathrm{ME}$. The samples were incubated at $50{ }^{\circ} \mathrm{C}$ for $30 \mathrm{~min}$ then centrifuged at $10000 \mathrm{~g}$ for $15 \mathrm{~min}$ at $4{ }^{\circ} \mathrm{C}$. The resulting pellet was either resuspended in the same extracting buffer and treated in the same manner, or it was resuspended in the sample buffer used for SDS-PAGE and boiled for 5 min before gel electrophoresis. The gels were scanned with a Zeineh scanning densitometer, soft laser $630 \mathrm{~nm}$, adjusting in each case the intensity of the most dense peak to about $80 \%$ of full scale.

Electron microscopy. The procedure described previously (Vasstrand \& Jensen, 1984) was followed throughout.

Other methods. Protein was estimated by a modified Lowry method as outlined by Markwell et al. (1978), and from amino acid analysis following hydrolysis in $4 \mathrm{M}-\mathrm{HCl}, 105^{\circ} \mathrm{C}, 16 \mathrm{~h}$, under vacuum (Vasstrand et al., 1980). Heptose was determined by the cysteine/ $\mathrm{H}_{2} \mathrm{SO}_{\downarrow}$ method according to Dische (1953). The difference in the absorbance between 510 and $540 \mathrm{~nm}$ was corrected for nonspecific absorbance in the blank and used as a relative measure of the concentration of heptose.

Lactate dehydrogenase and succinate dehydrogenase activities were analysed according to Owen et al. (1982), and ATPase according to Lanzetta et al. (1979).

\section{RESULTS}

The cell envelope was dominated by a few proteins (Fig. 1, lane 2). About $40 \%$ of the protein content of the cell envelope was soluble in Triton X-100 (Table 1; Fig. 1, lane 4), but the dominant proteins in the envelope fraction with molecular masses of 40 and $44 \mathrm{kDa}$ were not soluble in this detergent (Fig. 1, lane 3). The amounts of lactate dehydrogenase and succinate dehydrogenase found in the envelope preparations were too low for them to be utilized as marker enzymes for the inner membrane, but ATPase was found exclusively in the Triton X-100 soluble fraction (Table 1). Heptose, a constituent of the LPS of the cell wall (Hofstad, 1979), was found exclusively in the Triton X-100 insoluble (outer membrane) fraction (Table 1). Attempts to isolate pure outer and inner membranes by isopycnic centrifugation on sucrose gradients (Ito et al., 1977) failed. SDS-PAGE of heavy and light bands obtained by this procedure showed that 


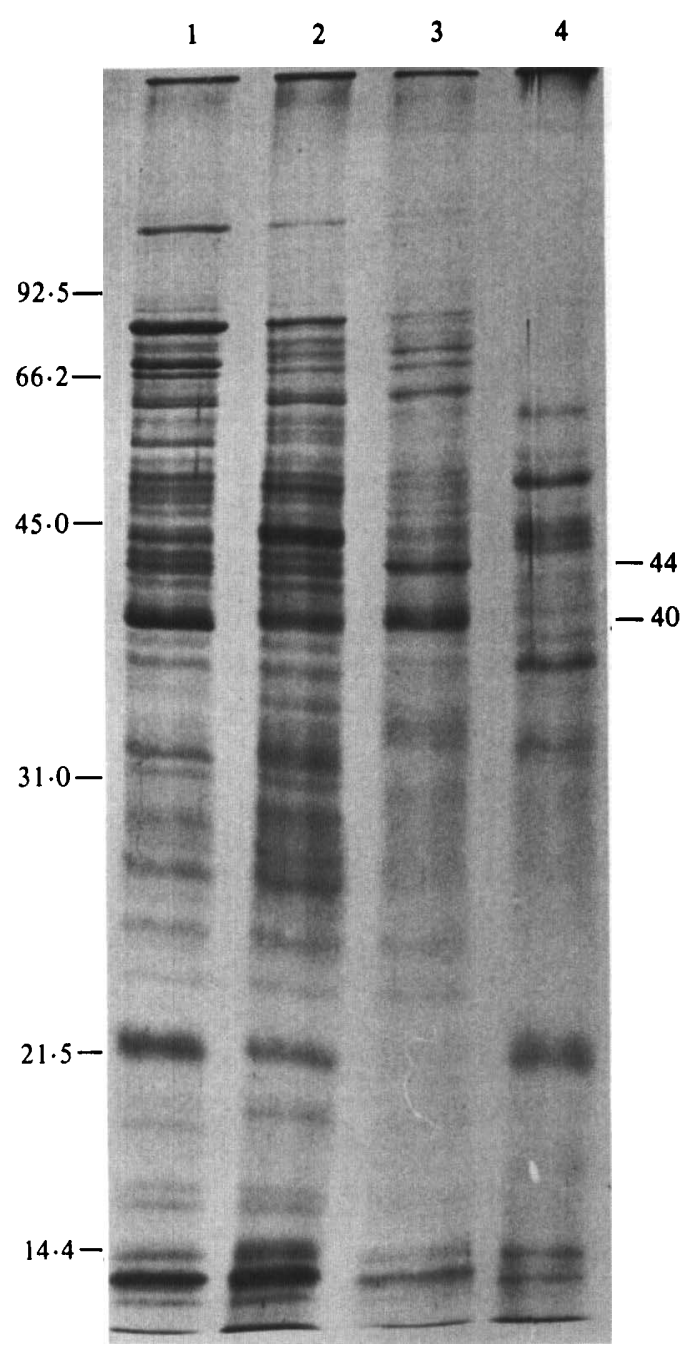

Fig. 1. SDS-PAGE analysis of proteins in F. mucleatum FevI. Lane 1, whole bacterial cells: lane 2, isolated cell walls from French pressed cells; lane 3, Triton X-100 insoluble cell wall fraction: lane 4 , Triton X-100 soluble cell wall fraction. Molecular mass standards ( $\mathrm{kDa}$ ) are indicated on the left. The gel was silver stained: 0.5 to $1.0 \mu \mathrm{g}$ protein was applied to each lane.

\section{Table 1. Analysis of cell envelope fractions obtained by Triton $X-100$ extraction}

Cell envelopes were prepared from 2.21 of cells $\left(\mathrm{OD}_{6,50} 0.51\right.$; wet weight $\left.3.87 \mathrm{~g}\right)$. The values presented are the means of two (heptose and ATPase) or three (protein and peptidoglycan) analyses.

\begin{tabular}{lccccc}
\multicolumn{1}{c}{ Fraction } & $\begin{array}{c}\text { Dry weight } \\
(\mathrm{mg})\end{array}$ & $\begin{array}{c}\text { Protein }+ \\
\text { peptidoglycin* } \\
(\mathrm{mg})\end{array}$ & $\begin{array}{c}\text { Peptidoglycan } \\
(\mathrm{mg})\end{array}$ & $\begin{array}{c}\text { Heptose } \\
\left({ }_{0}^{\circ}\right)\end{array}$ & ATPase + \\
Cell envelope & 369 & 196 & 32 & ND & ND \\
Triton soluble & 97 & 43 & 0 & 0 & $2 \cdot 0$ \\
Triton insoluble & 215 & 83 & 22 & 100 & $0 \cdot 0$
\end{tabular}

ND, Not determined.

* From amino acid analysis.

† From amino acid analysis, calculated from muramic acid and lanthionine.

$\ddagger$ Expressed as $\mu \mathrm{mol} \mathrm{ATP} \mathrm{(mg} \mathrm{protein})^{-1} \mathrm{~h}^{-1}$ at $37^{\circ} \mathrm{C}$. 

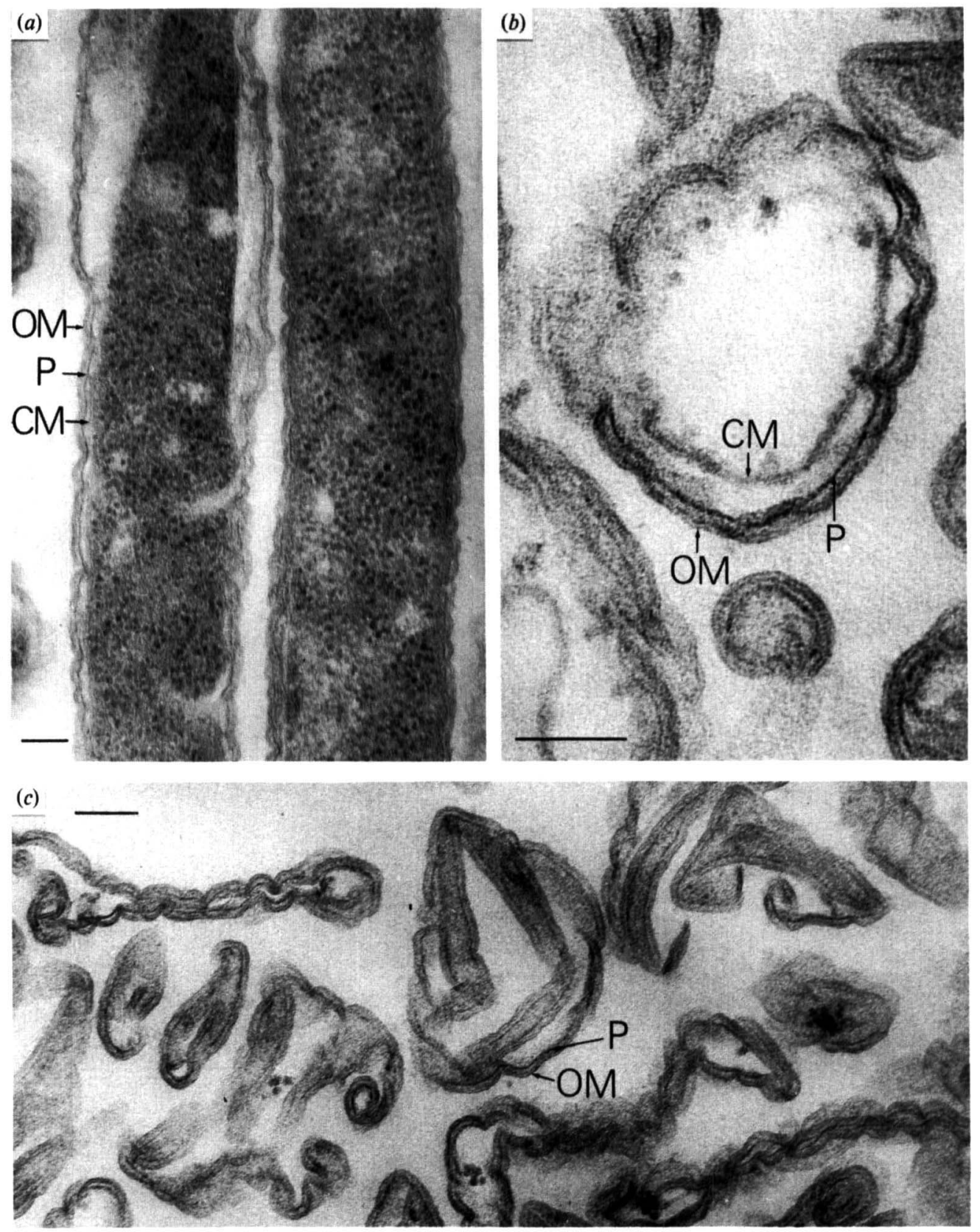

Fig. 2. Electron microscopy of $F$. nucleatum FevI. Sections through, intact cells $(a)$. French pressed cells $(b)$ and Triton $\mathrm{X}-100$ insoluble material (c). CM, cytoplasmic membrane: OM, outer membrane, P, peptidoglycan layer. Bars, $100 \mathrm{~nm}$.

the fractions were cross-contaminated by several proteins, and only approximately $65 \%$ of the heptose was recovered from the heavy and $35 \%$ from the light fractions.

The preparation of the cell wall fractions was also followed by electron microscopy. The three electron dense layers of the cell wall, corresponding to the outer membrane, the peptidoglycan and the cytoplasmic membrane, were observed both in whole cells (Fig. $2 a$ ) and in isolated cell walls (Fig. $2 b$ ). Less than $1 \%$ of the cells remained unbroken after the French press procedure. 


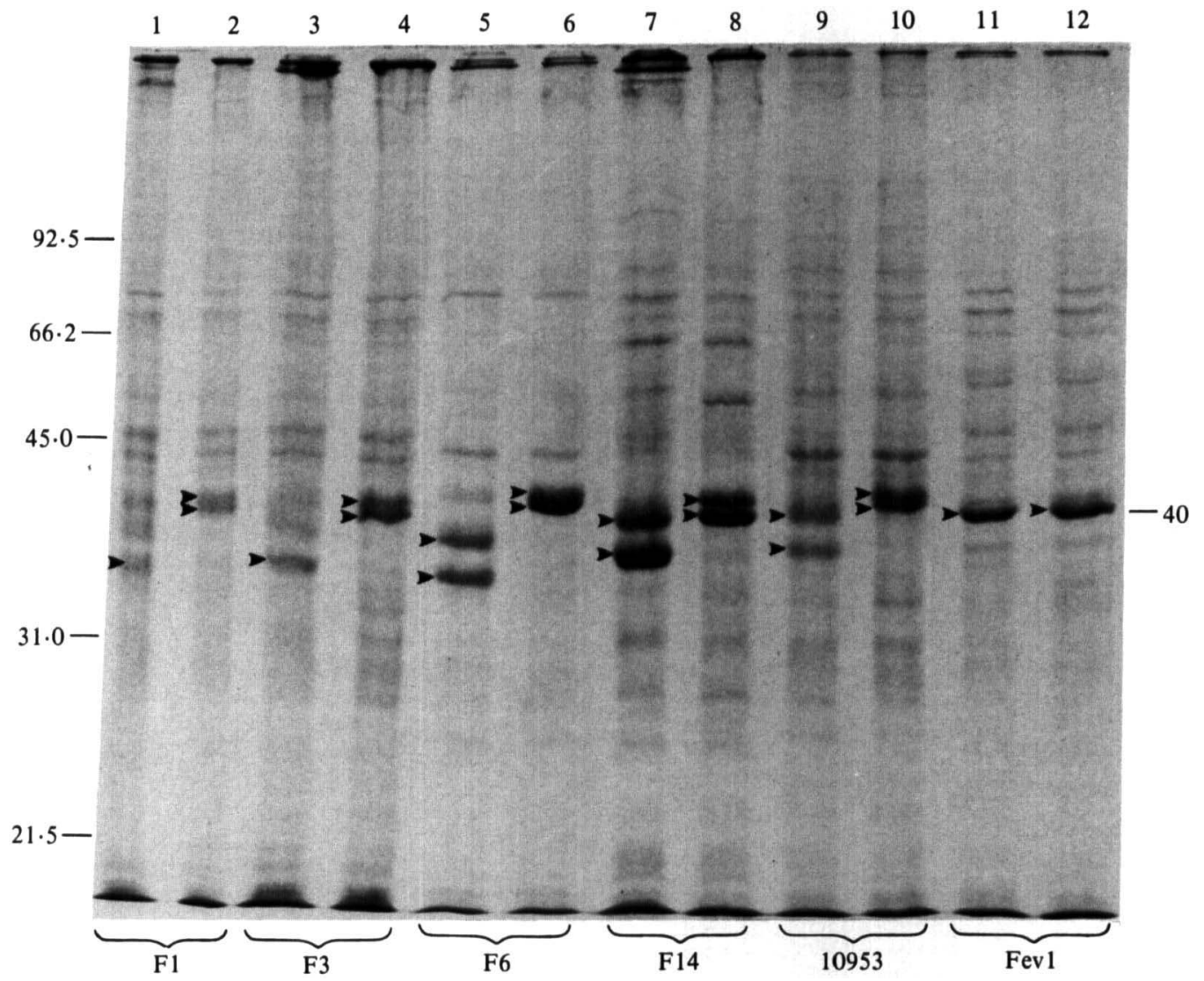

Fig. 3. SDS-PAGE analysis of outer membrane proteins (Triton X-100 insoluble cell wall) of six strains of $F$. nucleatum. The samples were heated for $5 \mathrm{~min}$ at $50^{\circ} \mathrm{C}$ (lanes $1,3,5,7,9$ and 11 ) or $100^{\circ} \mathrm{C}$ (lanes 2 , $4,6,8,10$ and 12). Proteins with changed mobility and the $40 \mathrm{kDa}$ protein of Fevl are arrowed. Molecular mass standards $(\mathrm{kDa})$ are indicated on the left. The gel contained $12.5 \%$ acrylamide and was stained with Coomassie brilliant blue.

The inner membrane could not be observed in the Triton X-100 insoluble cell wall material, whereas the double track layer of the outer membrane and the thin dark line, presumably representing the peptidoglycan, were still clearly visible (Fig. 2c). The peptidoglycan specific components lanthionine (Vasstrand et al., 1979) and muramic acid were found exclusively associated with the outer membrane fraction (Table 1). The Triton X-100 insoluble material retained its nature as a membrane in close association with the peptidoglycan (Fig. $2 c$ ), and was not merely aggregates of proteins insoluble in the detergent.

\section{Comparison between various strains of $F$. nucleatum}

The polypeptide composition of the outer membranes (i.e. Triton X-100 insoluble fractions) of six strains of $F$. nucleatum was compared. Gel profiles of outer membrane proteins were very similar in all the strains (Fig. 3), as were the patterns of inner membrane proteins (data not shown). When heated at $50{ }^{\circ} \mathrm{C}$ before electrophoresis, some proteins exhibited an increased mobility (Fig. 3). This was particularly evident with the proteins of molecular mass about $40 \mathrm{kDa}$ in all strains except Fevl, for which the profiles were identical at 50 and $100{ }^{\circ} \mathrm{C}$. The results with strains, F1, F3, F6, F14, and 10953 were very similar to those described previously (DiRienzo \& Rosan, 1984) for 10953 and some other strains of $F$. nucleatum. 


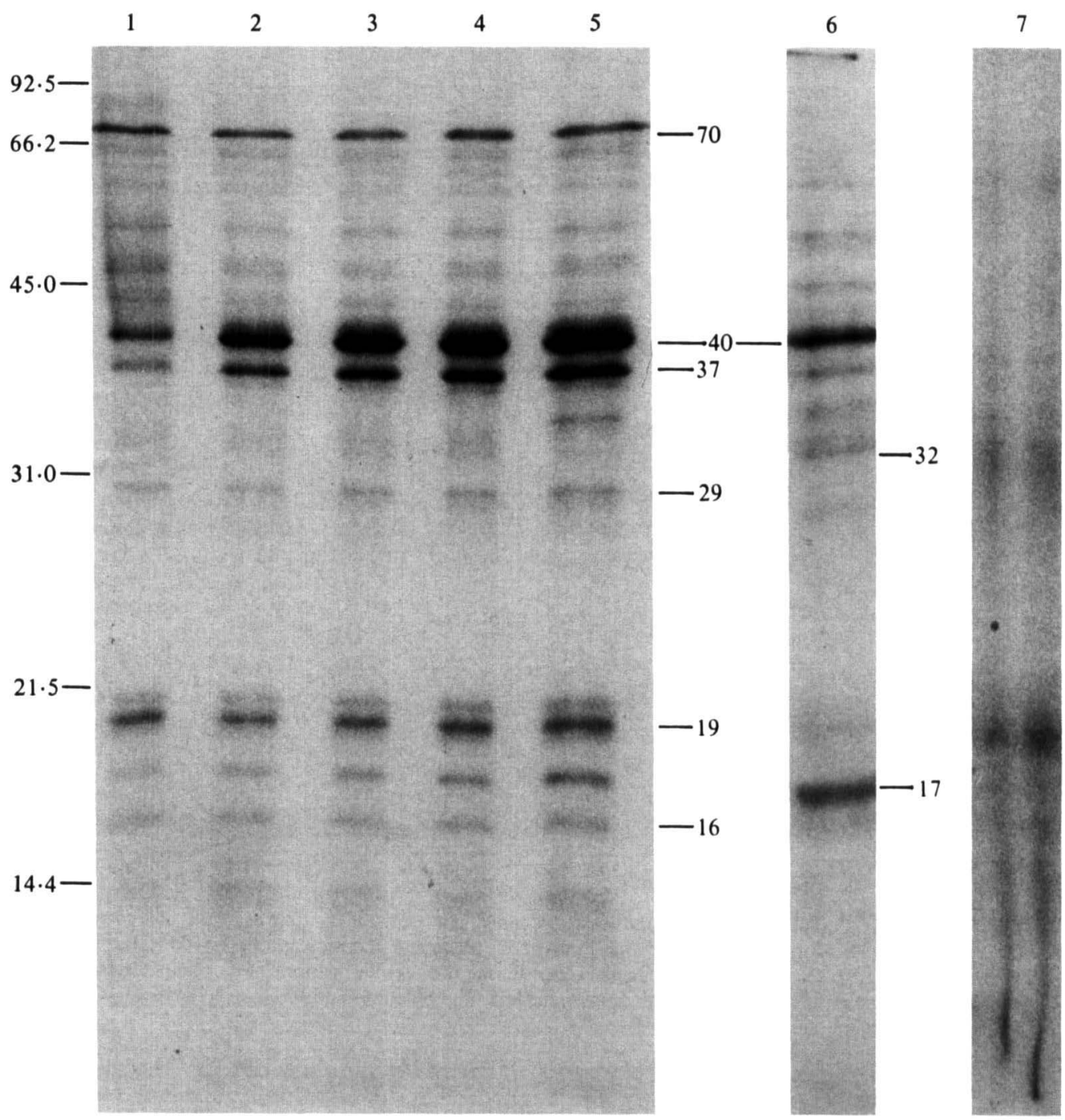

Fig. 4. SDS-PAGE analysis of outer membrane proteins from ${ }^{125}$ I-lactoperoxidase labelled cells. Outer membrane proteins were isolated by selective solubilization of inner membranes with Triton X100. Lanes 1-5: Triton $X-100$ insoluble fractions heated at different temperatures $(37,50,60,70$ and $100{ }^{\circ} \mathrm{C}$, respectively) before gel electrophoresis. Lane 6 : proteins insoluble after heating at $50{ }^{\circ} \mathrm{C}$ for $30 \mathrm{~min}$ in $2 \%$ SDS. Lane 7: Triton X-100 soluble cell wall fraction. Protein bands were detected by autoradiography. Molecular mass standards $(\mathrm{kDa})$ are indicated on the left.

\section{Radioiodination of surface exposed proteins}

The surface exposure of proteins of the outer membrane of $F$. nucleatum Fevl was investigated by extrinsic radiolabelling of live cells with ${ }^{125} \mathrm{I}$, by the lactoperoxidase method (Marchalonis, 1969). Outer membrane enriched material was isolated from these cells by Triton X-100 extraction of cell envelopes and analysed by SDS-PAGE and autoradiography (Fig. 4). Several proteins were isotopically labelled; again the $40 \mathrm{kDa}$ protein was dominant (Fig. 4, lane 5). Also proteins with apparent molecular masses of $70,50,37,32,29,19,17$ and $16 \mathrm{kDa}$ were labelled to some extent (Fig. 4), and, according to this criterion, exposed on the cell surface. In particular, the $37 \mathrm{kDa}$ protein was strongly labelled. On the other hand, no radioactive bands were evident in the Triton X-100 soluble cell wall material (lane 7), or from the cytoplasmic fraction (not shown), suggesting that the labelling indeed took place on the cell surface. Moreover, exactly the 
(a)

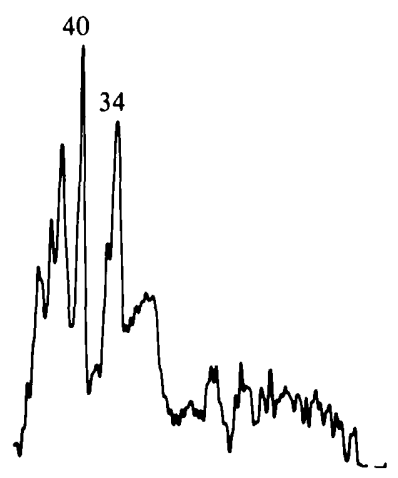

(b)

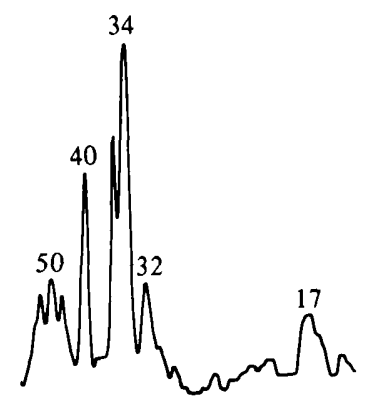

(c)<smiles>[Mg][Mg]</smiles>
34

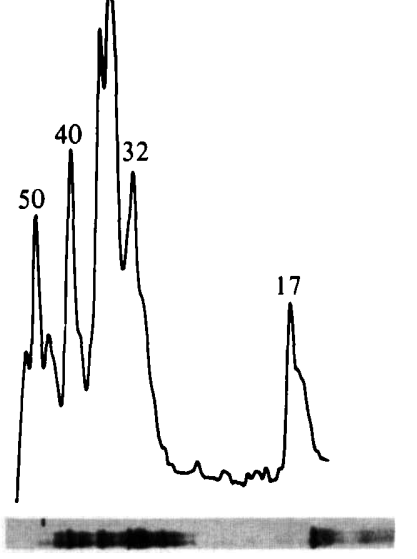

Fig. 5. Peptidoglycan associated proteins. The SDS-PAGE gels were stained with Coomassie blue and scanned. The scans show peptidoglycan-protein complexes after one $(a)$, two $(b)$ and three $(c)$ extractions with $2 \% \mathrm{SDS}$ at $50^{\circ} \mathrm{C}$. The numbers on the peaks indicate molecular masses (kDa).

same profile was obtained if labelling was done for $2 \mathrm{~min}$ or for $10 \mathrm{~min}$. When live $F$. nucleatum Fevl cells were dansylated prior to SDS-PAGE analysis of the whole cells, a very similar protein profile to that seen in Fig. 4, lane 5, was observed under UV light. The ${ }^{125}$ I-labelled outer membrane proteins were analysed with respect to heat modifiable properties (Fig. 4, lanes 1 to 5). The relative amounts of the $40 \mathrm{kDa}$ protein increased on going from 37 via 50 to $60{ }^{\circ} \mathrm{C}$ (see below).

\section{Association of peptidoglycan with the outer membrane proteins}

The peptidoglycan associated proteins of Escherichia coli are not released from the peptidoglycan by heating at $60^{\circ} \mathrm{C}$ in $2 \%$ SDS (Rosenbusch, 1974), and this method has been used to investigate peptidoglycan association in other Gram-negative bacteria. Gels stained with silver or Coomassie blue showed that the $40 \mathrm{kDa}$ protein was only partly soluble in the sample buffer at $37^{\circ} \mathrm{C}$ (not shown). Fig. 4, lane 6, shows the ${ }^{125}$ I-labelled proteins that were not solubilized upon heating at $50{ }^{\circ} \mathrm{C}$ for $30 \mathrm{~min}$ in $2 \% \mathrm{SDS}$. In addition to the $40 \mathrm{kDa}$ protein, several minor protein bands became visible. Compared to the outer membrane fraction (Fig. 4, lane 5) the pellet fraction was concentrated about eight-fold to obtain suitable amounts on the gel. From the relatively large increase in abundance of the $17 \mathrm{kDa}$ protein compared to that of the $40 \mathrm{kDa}$ protein (Fig. 4, lanes 5 and 6) one would expect the $17 \mathrm{kDa}$ protein to be particularly strongly bound to the peptidoglycan.

Peptidoglycan association was also determined using unlabelled cells by repeating the Rosenbusch procedure $\left(50{ }^{\circ} \mathrm{C}, 2 \% \mathrm{SDS}, 30 \mathrm{~min}\right)$ on the insoluble peptidoglycan-protein complex, and taking samples for SDS-PAGE analysis after each treatment. For convenient comparison of the relative strength of association, the Coomassie blue stained gels were scanned (Fig. 5). The $40 \mathrm{kDa}$ protein was still present after three extractions, but its relative abundance decreased compared to those of other proteins with apparent molecular masses of 50, 34-35, 32 and $17 \mathrm{kDa}$.

\section{DISCUSSION}

Whereas isopycnic centrifugation on sucrose gradients failed to separate pure outer and inner membranes, selective extraction of inner membrane proteins by Triton X-100 seemed to be very efficient. Selective solubilization of inner membranes by various detergents has provided a method for isolating outer membrane proteins of a wide variety of Gram-negative bacteria (Koval \& Murray, 1981; Moriyon \& Berman, 1982; Owen et al., 1982; Schnaitman, 1971). Very little cross-contamination of proteins in the Triton X-100 soluble and insoluble fractions was 
found (Fig. 1), and the cytoplasmic membrane marker ATPase was found exclusively in Triton $\mathrm{X}-100$ soluble material and the LPS constituent heptose exclusively in the Triton X-100 insoluble material (Table 1). Moreover, electron micrographs indicated that the Triton X-100 insoluble material was predominantly outer membrane in close association with the peptidoglycan. Accordingly, extrinsic ${ }^{125}$ I-labelled material was recovered exclusively from the Triton X-100 insoluble fraction, suggesting that the labelling actually took place on the cell surface, and that the detergent did not solubilize outer membrane proteins. The present work thus indicated that $F$. nucleatum Fevl cells have an outer membrane that is quite similar in many respects to those of other Gram-negative organisms. Good separation of inner and outer membranes by isopycnic centrifugation usually depends on efficient formation of spheroplasts (Owen et al., 1982). The effect of lysozyme on $F$. nucleatum Fevl seems to be rather atypical (Vasstrand \& Jensen, 1984), and we suspect that the reason for the failure to obtain pure outer and inner membranes by this procedure is to be found in this step.

Some of the outer membrane proteins are evidently among the most abundant proteins in the cell. A $40 \mathrm{kDa}$ protein was responsible for the major band and this dominated the SDS-PAGE profile of the cell envelope, and was also clearly seen when whole cells were applied to the gels (Fig. 1).

The polypeptide composition of the outer membranes of the six strains of $F$. nucleatum examined (F1, F3, F6, F14, 10953 and Fev1) showed a high degree of homology in relation to molecular masses. There was, however, a clear difference when heat modifiable properties were examined. Thus, in all strains except Fevl, one of the most abundant outer membrane proteins exhibited heat modifiable properties. None of the outer membrane proteins of $F$. nucleatum Fevl exhibited any detectable heat modifiable properties even after boiling for $30 \mathrm{~min}$. This seems to be a strain specific property. DiRienzo \& Rosan (1984) have recently published data on a major envelope protein from $F$. nucleatum strain 364 with an apparent molecular mass of $50 \mathrm{kDa}$ and $35.5 \mathrm{kDa}$ at $100{ }^{\circ} \mathrm{C}$ and $50{ }^{\circ} \mathrm{C}$, respectively. Similar results were reported for strain 10953 (DiRienzo \& Spieler, 1983). Our results indicated that the shift in apparent molecular mass of the heat modifiable proteins of strain 10953, as well as strains F1, F3, F6, and F14, was from about $38 \mathrm{kDa}$ to about $42 \mathrm{kDa}$. Such differences in the actual values observed could be due to the different techniques used (Lugtenberg \& Van Alphen, 1983). The $40 \mathrm{kDa}$ protein of $F$. nucleatum Fevl was exposed at the cell surface, as determined by the ${ }^{125}$ I-lactoperoxidase method, and was peptidoglycan associated as defined by Rosenbusch (1974). It should be emphasized, however, that the Rosenbusch procedure does not by itself establish that the protein is actually bound to the peptidoglycan, rather than being present as an insoluble protein aggregate. However, purified $40 \mathrm{kDa}$ protein, freed from peptidoglycan by centrifugation after heating to $50{ }^{\circ} \mathrm{C}$ or higher, was soluble in $2 \%$ SDS at room temperature.

The $40 \mathrm{kDa}$ protein was often seen in gels as a doublet (e.g. Fig. 1, lane 3 and Fig. 4, lane 5). The presence of similar doublets in the corresponding proteins in the other strains was also indicated (Fig. 3). Further separation of proteins in the $40 \mathrm{kDa}$ region will be attempted by twodimensional electrophoresis.

In addition to the major $40 \mathrm{kDa}$ protein, several other proteins were apparently exposed on the cell surface (Fig. 4). Some of these surface exposed proteins were also peptidoglycan associated, in particular a $32 \mathrm{kDa}$ and a $17 \mathrm{kDa}$ protein. It is thus possible that these proteins, and the $40 \mathrm{kDa}$ protein, are involved in formation of pores or channels (DiRienzo et al., 1978; Lugtenberg \& Van Alphen, 1983), which seems to be universally found in the outer membrane of Gram-negative bacteria. Variations with growth conditions in the amount of these proteins, and of the outer membrane proteins in general, are under investigation.

It has been suggested that the D-diaminopimelic acid residue of the peptidoglycan plays an important role in its binding to the matrix protein in E. coli (DiRienzo et al., 1978). Lanthionine, the monosulphur analogue of diaminopimelic acid, replaces diaminopimelic acid in $F$. nucleatum Fevl (Vasstrand et al., 1979, 1982);85\% is recovered as meso-lanthionine and $15 \%$ as DL-lanthionine (Vasstrand et al., 1979). The question arises whether these isomers of lanthionine play any role in the association between the $40 \mathrm{kDa}$ protein and the peptidoglycan in this organism. 
We are grateful to $T$. Thorsen for help with the radioiodination experiments, P. G. Krüger for help and guidance during electron microscopy, E. Vasstrand for valuable discussions and B. Høgh for excellent technical assistance. This investigation was supported by the Norwegian Research Council for Science and the Humanites.

\section{REFERENCES}

Blaser, M. J., Hopkins, J. A. \& Vasil, M. L. (1984). Campylobacter jejuni outer membrane proteins are antigenic for humans. Infection and Immunity 43, 986-993.

Buchanan, T. M. \& Pearce, W. A. (1979). Pathogenic aspects of outer membrane components of Gramnegative bacteria. In Bacterial Outer Membranes, pp. 475-514. Edited by M. Inoye. New York: John Wiley.

Dahlén, G., Nygren, H. \& Hansson, H.-A. (1978). Immunoelectronmicroscopic localization of lipopolysaccharides in the cell wall of Bacteroides oralis and Fusobacterium nucleatum. Infection and Immunity 19, 265-271.

Dehazya, P. \& Coles, R. S. JR (1980). Agglutination of human erythrocytes by Fusobacterium nucleatum: factors influencing hemagglutination and some characteristics of agglutinin. Journal of Bacteriology 143, 205-211.

Dehazya, P. \& Coles, R. S., JR (1982). Extraction and properties of hemagglutinin from cell wall fragments of Fusobacterium nucleatum. Journal of Bacteriology 152, 298-3095.

DiRienzo, J. M. \& Rosan, B. (1984). Isolation of a major cell envelope protein from Fusobacterium nucleatum. Infection and Immunity 44, 386-393.

DiRienzo, J. M. \& SPIEler, E. L. (1983). Identification and characterization of the major cell envelope proteins of oral strains of Actinobacillus actinomycetemcomitans. Infection and Immunity 39, 253-261.

DiRienzo, J. M., NaKamura, K. \& InOye, M. (1978). The outer membrane proteins of Gram-negative bacteria: biosynthesis, assembly and functions. Annual Review of Biochemistry 47, 481-532.

Dische, Z. (1953). Qualitative and quantitative colorimetric determination of heptoses. Journal of Biological Chemistry 204, 983-997.

Falkler, W. A. \& Hawley, C. E. (1977). Hemagglutinating activity of Fusobacterium nucleatum. Infection and Immunity 15, 230-238.

Gilleland, H. E., JR, Parker, M. G., Matthews, J. M. \& BERG, R. D. (1984). Use of a purified outer membrane protein F (porin) preparation of Pseudomonas aeruginosa as a protective vaccine in mice. Infection and Immunity 44, 49-54.

Hofstad, T. (1979). Serological responses to antigens of Bacteriodaceae. Microbiological Reviews 43, 103115.

HofsTAD, T. (1981). The genus Fusobacterium. In The Prokaryotes. A Handbook on Habitats, Isolation and Identification of Bacteria, pp. 1464-1474. Edited by M. P. Starr, H. Stolp, H. G. Trüper, A. Balows \& H. G. Schlegel. Berlin \& Heidelberg: Springer.

Hofstra, H., Van Tol, M. J. D. \& DanKerT, J. (1980). Cross-reactivity of major outer membrane proteins of Enterobacteriaceae, studied by crossed immunoelectrophoresis. Journal of Bacteriology' 143, 328-337.
Ito, K., Sato, T. \& Yura, T. (1977). Synthesis and assembly of the membrane proteins in Escherichia coli. Cell 11, 551-559.

Koval, S. F. \& Murray, R. G. E. (1981). Cell wall proteins of Aquaspirillium serpens. Journal of Bacteriology 146, 1083-1090.

KRISTOFFERSEN, T. (1969a). Immunochemical studies of oral fusobacteria. 3. Purification of a group reactive precipitinogen. Acta pathologica et microbiologica scandinavica 77, 447-456.

KRISTOFFERSEN, T. $(1969 b)$. Immunochemical studies of oral fusobacteria. 4. Some chemical properties of a group reactive precipitinogen. Acta pathologica et microbiologica scandinatica 77, 457-464.

LAEMMLI, U. K. (1970). Cleavage of structural proteins during assembly of the head of bacteriophage T4. Nature, London 227, 680-685.

Lancy, P., JR, DiRienzo, J. M., Appelbaum, B., Rosan, B. \& Holt, S. C. (1983). Corncob formation between Fusobacterium nucleatum and Streptococcus sanguis. Infection and Immunity 40, 303-309.

Lanzetta, P. A., Alvarez, L. J., Reinach, P. S. \& Candia, O. A. (1979). An improved assay for nanomole amounts of inorganic phosphate. Analytical Biochemistry 100, 95-97.

Lugtenberg, B. \& VAN Alphen, L. (1983). Molecular architecture and functioning of the outer membrane of Escherichia coli and other Gram-negative bacteria. Biochimica et biophysica acta 737, 51-115.

MarChalonis, J. J. (1969). An enzymatic method for trace iodination of immunoglobulins and other proteins. Biochemical Journal 113, 299-305

Markwell, M. A. K., HaAs, S. M., Bieber, L. L. \& TOLBERT, N. E. (1978). A modification of the Lowry procedure to simplify protein determination in membrane and lipoprotein samples. Analytical Biochemistry 87, 206-210.

MARShall, T. \& LATNER, A. L. (1981). Incorporation of methylamine in an ultrasensitive silver stain for detecting protein in thick polyacrylamide gels. Electrophoresis 2, 228-235.

MORIYON, I. \& BERMAN, D. T. (1982). Effects of nonionic, ionic, and dipolar ionic detergents and EDTA on the Brucella cell envelope. Journal of Bacteriology 152, 822-828.

Owen, P., Craeme-Cook, A., Crowe, B. A. \& Condon, C. (1982). Bacterial membranes: preparative techniques and criteria of purity. In Techniques in Lipid and Membrane Biochemistry Part 1, pp. 1-69. Edited by T. R. Hesketh, H. L. Kornberg, J. C. Metcalf, D. H. Northcote, C. I. Pogson \& K. F. Tipton. Amsterdam: Elsevier North-Holland.

RosenbusCh, J. P. (1974). Characterization of the major envelope protein from Escherichia coli. Regular arrangement on the peptidoglycan and unusual dodecyl sulfate binding. Journal of Biological Chemistr. 249, 8019-8029. 
Schnaltman, C. A. (1971). Solubilization of the cytoplasmic membrane of Escherichia coli by Triton X-100. Journal of Bacteriology' 108, 545-552.

SOCRANSKY, S. S. (1970). Relationship of bacteria to the etiology of periodontal disease. Journal of Dental Research 49, 203-222.

Van Palenstein-Helderman, W. H. (1975). Total viable count and differential count of Vibrio (Campylohacter) sputorum, Fusohacterium nucleatum, Bacteroides ochraceus and Veillonella in the inflamed and non-inflamed human gingival crevice. Journal of Periodontal Research 10, 294-305.

Vasstrand, E. N. \& Jensen, H. B. (1984). Antibacterial properties of human lysozyme toward Fusobacterium nucleatum Fev1. Scandinatian Journal of Dental Research 92, 109.119.
Vasstrand, E. N., Hofstad, T., Endresen, C. \& JeNSEN, H. B. (1979). Demonstration of lanthionine as a natural constituent of the peptidoglycan of Fusobacterium nucleatum. Infection and Immunity' 25. 775-780.

Vasstrand, E. N., Jensen, H. B. \& Miron, T. (1980) Microbore single-column analysis of amino acids and amino sugars specific to bacterial cell wall peptidoglycans. Analytical Biochemistry 105, 154 . 158.

Vasstrand, E. N., Jensen, H. B., Miron, T. \& HoFsTAD, T. (1982). Composition of peptidoglycans in Bacteriodaceae. Determination and distribution of lanthionine. Infection and Immunity 36, 114 122. 